Christian Werner MD, ${ }^{*}$ Eberhard Kochs MD MSc, ${ }^{*}$ William E. Hoffman PhD, $\dagger$ Irmgard F. Blanc MD,* Jochen Schulte am Esch $\mathrm{MD}^{*}$

\title{
Cerebral blood flow and cerebral blood flow velocity during angio- tensin-induced arterial hypertension in dogs
}

Pressure-passive perfusion beyond the upper limit of cerebral blood flow (CBF) autoregulation may be deleterious in patients with intracranial pathology. Therefore, monitoring of changes in $\mathrm{CBF}$ would be of clinical relevance in situations where clinical evaluation of adequate cerebral perfusion is impossible. Noninvasive monitoring of cerebral blood flow velocity using transcranial Doppler sonography (TCD) may reflect relative changes in CBF. This study correlates the effects of angiotensininduced arterial hypertension on $C B F$ and cerebral blood flow velocity in dogs. Heart rate (HR) was recorded using standard ECG. Catheters were placed in both femoral arteries and veins for measurements of mean arterial blood pressure (MAP), blood sampling and drug administration. A lefi ventricular catheter was placed for injection of microspheres. Cerebral blood flow velocity was measured in the basilar artery through a cranial window using a pulsed $8 \mathrm{MHz}$ transcranial Doppler ultrasound system. CBF was measured using colour-labelled microspheres. Intracranial pressure (ICP) was measured using an epidural probe. Arterial blood gases, arterial $\mathrm{pH}$ and body temperature were maintained constant over time. Two baseline measures of HR, MAP, CBF, cerebral blood flow velocity and

\section{Keywords}

BRAIN: blood flow;

MEASUREMENT TECHNIQUES: blood flow, Doppler ultrasound, microspheres;

POLYPEPTIDES: angiotensin.

From the Departments of Anaesthesiology, *University Hospital Eppendorf, 2000 Hamburg 20, Germany. †Humana Hospital Michael Reese and University of Illinois College of Medicine, Chicago, IL 60612, U.S.A.

Address correspondence to: Dr. Christian Werner,

Department of Anaesthesiology, University Hospital Eppendorf, Martinistrasse 52, 2000 Hamburg 20, Germany. Tel: 40-4717-2415; Fax: 40-4717-4963.

Presented in part at the Annual Meeting of the International Anesthesia Research Society, Hawaii, U.S.A., 1990.

Accepted for publication 15th April, 1993.
ICP were made in all dogs $(n=10)$ using etomidate infusion ( $1.5 \mathrm{mg} \cdot \mathrm{kg}^{-1} \cdot \mathrm{hr}^{-1}$ ) and $70 \% \mathrm{~N}_{2} \mathrm{O}$ in $\mathrm{O}_{2}$ as background anaesthesia. Following baseline measurements, a bolus of $1.25 \mathrm{mg}$ angiotensin was injected $i v$ and all variables were recorded five minutes after the injection. Mean arterial blood pressure was increased by $76 \%$. Heart rate and ICP did not change. Changes in MAP were associated with increases in cortical CBF (78\%), brainstem CBF (87\%) and cerebellum CBF (64\%). Systolic flow velocity increased by $27 \%$ and Vmean increased by $31 \%$ during hypertension $(P<0.05)$. Relative changes in $C B F$ and blood flow velocity were correlated (CBF cortex $-V$ syst: $r=0.94$, CBF cortex - Vmean: $r=0.77 ; P<0.001 ; C B F$ brainstem - Vsyst: $r=0.82, C B F$ brainstem - Vmean: $r=0.69 ; P$ $<0.05$ ). Our results show that increases in arterial blood pressure beyond the upper limit of cerebral autoregulation increase $\mathrm{CBF}$ in dogs during etomidate and $\mathrm{N}_{2} \mathrm{O}$ anaesthesia. The changes in $C B F$ are correlated with increases in basilar artery blood flow velocity. These data suggest that TCD indicates the upper limit of the cerebral autoregulatory response during arterial hypertension. However, the amount of CBF change may be underestimated with the TCD technique.

La pression passive de perfusion cérébrale au-dessus du seuil supérieur de l'autorégulation du débit sanguin cérébral (CBF) peut être fatale chez des patients atteints de pathologie intracrânienne. Ainsi le monitorage du changement du CBF sera important dans les cas où l'évaluation clinique d'une perfusion cérébrale adéquate n'est pas possible. Le monitorage de la vélocité du flot sanguin cérébral par un doppler transcrânien peut refléter des changements relatifs du CBF. Cette étude met en corrélation les effets de lhypertension artérielle provoqués par l'angiotensine sur le flot sanguin cérébral local (rCBF) et la vélocité du débit sanguin cérébral chez des chiens. La fréquence cardiaque a été enregistrée en continu (ECG). Pour mesurer la pression artérielle moyenne (MAP), pour les prélèvements sanguins et l'administration des médicaments, des cathéters ont été placés dans les artères et veines fémorales. Pour une injection des microsphères, un cathéter a été placé dans le ventricule gauche. La velocité du flot sanguin cérébral a été mesurée au niveau du tronc basilaire par une fenêtre osseuse en utilisant 
un doppler transcrânien pulsé $8 \mathrm{MHz}$ (TCD). CBF a été mesuré en utilisant des microsphères colorées. La pression intracrânienne (ICP) a été mésurée par sonde épidurale. Les gaz sanguins artériels, le $\mathrm{pH}$ artériel et la température corporelle ont été maintenus constants pendant toute la durée du protocole. Deux mesures de contrôle de tous les paramètres $M A P$, $H R, C B F$, de la vélocité du flot sanguin et ICP ont été enregistrées chez tous les chiens $(n=10)$ anesthésiés par linfusion d'étomidate (1,5 $\left.\mathrm{mg} \cdot \mathrm{kg}^{-1} \cdot \mathrm{hr}^{-1}\right)$ et au protoxyde d'azote (70\%) dans l'oxygène. Après ces mesures de contrôle, un bolus d'angiotensine $1,25 \mathrm{mg}$ a été injecté et tous les paramètres ont été enregistrés cinq minutes après linjection. MAP a augmenté de $76 \%$. La fréquence cardiaque et la pression intracrânien n'ont pas changé. Les changements de la pression artérielle moyenne ont été associés aux changements significatifs du CBF cortical (78\%), du CBF du tronc cérébral (87\%) et du CBF du cervelet (64\%). Pendant la durée de l'hypertension, Vsyst a augmenté de $27 \%$ et Vmoyenne de $31 \%(P<0.05)$. Il y a eu une corrélation entre les changements relatifs du CBF et la vélocité du débit sanguin cérébral (CBF cortex $-V_{\text {syst }} r=0,94, C B F$ cortex - Vmoyenne: $r=0,77 ; P<0,001 ; C B F$ tronc cérébral - Vsyst: $r=0,82, C B F$ tronc cérébral - Vmoyenne: $r=0,69$; $P<0,05)$. Nos résultats montrent que chez des chiens anesthésiés au protoxyde d'azote et à l'étomidate, les augmentations de la pression artérielle au-dessus de la limite supérieure de l'autorégulation cérébrale augmentent le flot sanguin cérébral global et régional. Il y a une corrélation entre les changements du CBF et les augmentations de la vélocité du flot sanguin du tronc basilaire. Ces données suggèrent que TCD indique la limite supérieure de l'autorégulation cérébrale pendant la durée de l'hypertension artérielle. Cependant, le taux du changement du CBF peut être sous-estimé par la technique du TCD.

In mammals, cerebral blood flow (CBF) is kept constant over a wide range of mean arterial blood pressure by cerebral autoregulation. ${ }^{1}$ Considerable changes in mean arterial blood pressure may frequently occur at any stage during anaesthesia and critical care and pressuredependent increases can produce deleterious raises in intracranial pressure. Additionally, the limits of cerebral autoregulation are not predictable since anaesthetics, cerebral vascular disorders or chronic arterial hypertension may alter the autoregulatory response. ${ }^{2}$ Monitoring of the limits of cerebral autoregulation would be of considerable clinical value particularly in situations where clinical evaluation of adequate cerebral perfusion is impossible in order to avoid hypo- or hyperperfusion of the brain. Several experimental and clinical studies indicate that noninvasive transcranial Doppler sonography (TCD) may be used to monitor relative changes in CBF with $i v$ anaesthetics and narcotics or during hypercapnia and cardiopulmonary bypass. ${ }^{3-6}$ It has not been determined whether TCD patterns reflect changes in cerebral perfusion due to increases in arterial blood pressure. The present study investigates the effects of extreme arterial hypertension on CBF in correlation to cerebral blood flow velocity in dogs.

\section{Methods}

The present experiments were approved by the Institutional Animal Care Committee. Ten male fox-hounds $(24 \pm 3 \mathrm{~kg})$ were anaesthetized with a bolus injection of $0.8 \mathrm{mg} \cdot \mathrm{kg}^{-1}$ etomidate, their tracheas were intubated and their lungs ventilated mechanically. Anaesthesia was maintained with a continuous infusion of 1.5 $\mathrm{mg} \cdot \mathrm{kg}^{-1} \cdot \mathrm{hr}^{-1}$ etomidate and $70 \%$ nitrous oxide $\left(\mathrm{N}_{2} \mathrm{O}\right)$ in oxygen. Fentanyl infusion $\left(50 \mu \mathrm{g} \cdot \mathrm{kg}^{-1} \cdot \mathrm{hr}^{-1}\right)$ was given for the period of surgical preparation. Vecuronium infusion $\left(0.2 \mathrm{mg} \cdot \mathrm{kg}^{-1} \cdot \mathrm{hr}^{-1}\right)$ was used for muscle relaxation. Body temperature was maintained at $38^{\circ} \mathrm{C}$ using a servocontrol heating lamp connected to a rectal thermistor probe. Heart rate (HR, beats $\cdot \min ^{-1}$ ) was recorded by standard ECG leads. Catheters were inserted into both femoral arteries and veins for continuous measurement of mean arterial blood pressure (MAP, $\mathrm{mmHg}$ ), arterial blood sampling and drug administration. A catheter was placed into the left cardiac ventricle in a retrograde fashion via the femoral artery for later injection of microspheres. A $35 \mathrm{~mm}$ cranial window was drilled in the vertex area between both parietal bones. A pulsed $8 \mathrm{MHz}$ Doppler ultrasound probe was placed on the intact dura to measure blood flow velocity in the basilar artery (BA). The probe was then fixed in a frame in order to keep insonation depth and insonation angle constant over time. Blood flow velocity and pulsatility index were measured continuously using a pulsed transcranial Doppler system (TC2-64 B ${ }^{\top}$, EME). Intracranial pressure (ICP, $\mathrm{mmHg}$ ) was measured using an epidural Gaeltec probe. At the end of surgery, all incisions were infiltrated with bupivacaine $0.25 \%$ and all animals were subjected to an equilibration period of $30 \mathrm{~min}$. Arterial blood gases and arterial $\mathrm{pH}$ were maintained constant over time. Two baseline measurements of all variables were performed within $15 \mathrm{~min}$. Following baseline measurements, a bolus of angiotensin $1.25 \mathrm{mg}$ was injected $i v$ over one minute. The third measurement was performed five minutes following induction of arterial hypertension.

\section{Measurements of cerebral blood flow}

Cerebral blood flow was measured in a randomized fashion using three species of coloured $11.9 \pm 1.9 \mu \mathrm{m}$ polystyrene microspheres (E-Z Trac, Los Angeles, U.S.A.). Stock solutions containing $1 \times 10^{8}$ microspheres $\cdot \mathrm{ml}^{-1}$ 
were suspended in isotonic saline with Tween-80 $0.025 \%$. Microspheres were vortexed for one minute, and $5 \mathrm{ml}$ were injected into the left ventricle and the catheter flushed with saline. Reference blood samples (10 $\mathrm{ml} \cdot \mathrm{min}^{-1}$ ) were withdrawn from the femoral artery starting $30 \mathrm{sec}$ before each microsphere injection and continuing $90 \mathrm{sec}$ after each injection. At the end of the experiments the dogs were killed by injection of $20 \% \mathrm{KCl}$, the brain removed and 1.5-3 $\mathrm{g}$ of tissue dissected bilaterally from the following regions: cortex (represented by frontal, vertex and parieto-temporal tissue) brain stem and cerebellum. The numbers of tissue and blood microspheres were counted using an Improved Neubauer Hemocytometer. Twelve chambers were counted for each sample, and the total number of microspheres in each reference blood and tissue sample was computed with the formula: Total microspheres $=$ (no. counted $/$ no. chambers $\left.\times 0.9 \mathrm{~mm}^{3}\right) \times\left(1.000 \mathrm{~mm}^{3} / \mathrm{ml}\right) \times$ ml suspension. In this formula, no. counted is the number of coloured microspheres counted, no. chambers is the number of chambers counted, $0.9 \mathrm{~mm}^{3}$ is the ruled volume of the chamber, and $\mathrm{ml}$ suspension is the final dilution volume. The CBF (ml $\left.100 \mathrm{~g}^{-1} \cdot \mathrm{min}^{-1}\right)$ was calculated according to the method of Hale et al. ${ }^{7}$ using the formula: $\mathrm{CBF}=$ (total no. tissue sample microspheres $X$ reference flow rate)/(total no. reference blood sample microspheres $X$ tissue sample weight). Cerebral vascular resistance $\left(\mathrm{mmHg} \cdot \mathrm{ml}^{-1} \cdot 100 \mathrm{~g}^{-1} \cdot \mathrm{min}^{-1}\right)$ was calculated for each CBF measurement (CVR = (MAP - ICP)/ CBF).

\section{Transcranial Doppler sonography measurements}

Basilar artery blood flow velocity was measured continuously for correlation with CBF using a pulsed $8 \mathrm{MHz}$ transcranial Doppler system (TC2-64 Bं Electronics, Germany). Blood flow velocity data were integrated over the time of reference blood sampling (120 $\mathrm{sec}$ ). The system operates with $100 \mathrm{~mW}$ ultrasonic intensity and pulse repetition frequencies between $4.96 \mathrm{kHz}$ and $20.52 \mathrm{kHz}$. A range-gate is used to adjust the ultrasonic focus electronically in steps of $2.5 \mathrm{~mm}$. The axial extension of the sample volume measures $10 \mathrm{~mm}$ according to a burst width of $13 \mu \mathrm{sec}$. A high-pass filter of $150 \mathrm{~Hz}$ and a low-pass filter of $9 \mathrm{kHz}$ are set for signal registration. Signals are computed using spectral analysis by 64 -point Fast Fourier Transformation, averaging cycles of 4 to $20 \mathrm{sec}$. Following Doppler shift calculation and flow direction discrimination, the flow velocity profile is displayed in real-time on a video monitor. The instantaneous systolic (Vsyst, $\mathrm{cm} \cdot \mathrm{sec}^{-1}$ ) and mean flow velocity (Vmean, $\mathrm{cm} \cdot \mathrm{sec}^{-1}$ ) and the pulsatility index (PI), calculated by the formula: PI = (Vsyst - Vdiast $) /$ Vmean, are digitally displayed for each flow spectrum.
TABLE I Arterial blood bases, $\mathrm{pH}$ and systemic haemodynamic variables before and after induction of arterial hypertension

\begin{tabular}{llllll}
\hline & $\mathrm{PO}_{2}$ & $\mathrm{PCO}_{2}$ & $p H$ & $\mathrm{HR}$ & $M A P$ \\
\hline Baseline 1 & $140 \pm 6$ & $39 \pm 1$ & $7.36 \pm 0.01$ & $73 \pm 4$ & $134 \pm 3$ \\
Baseline 2 & $148 \pm 6$ & $39 \pm 1$ & $7.36 \pm 0.01$ & $74 \pm 5$ & $135 \pm 6$ \\
Hypertension & $124 \pm 9$ & $39 \pm 1$ & $7.36 \pm 0.01$ & $76 \pm 9$ & $236 \pm 11^{*}$ \\
\hline
\end{tabular}

$\mathrm{PO}_{2}$ : arterial oxygen tension in $\mathrm{mmHg} ; \mathrm{PCO}_{2}$ : arterial dioxide tension in $\mathrm{mmHg}$; HR: heart rate in beats $\mathrm{min}^{-1}$; MAP: mean arterial pressure in $\mathrm{mmHg}$; mean $\pm \mathrm{SEM}$. $* P<0.001$.

\section{Statistics}

All data are reported as mean \pm SEM. A repeated measures analysis of variance was used to compare treatment effects for all physiological variables. Multiple post-hoc comparisons of physiological variables across time were made using the Tukey test. "Pearson product moment correlations" were used to determine the relationship between TCD data and cerebral haemodynamic variables.

\section{Results}

Blood gas tensions, $\mathrm{pH}$ and systemic haemodynamic variables are shown in Table I. Arterial blood pressure was the same during the two baseline measurements and was increased following angiotensin injection $(P<0.001)$. All other measurements did not change with repeated testing.

Regional CBF, ICP and TCD data are shown in Table II. Regional CBF did not change during the two baseline measurements. During arterial hypertension cortical CBF increased by $78 \%$, brainstem CBF by $87 \%$ and cerebellum CBF $64 \%$. The ICP and CVR did not change and PI increased $42 \%$ during hypertension. The Vsyst and Vmean increased by $27 \%$ and $31 \%$, respectively $(P<$ 0.05). Relative changes in CBF and blood flow velocity were correlated (CBF cortex - Vsyst: $r=0.94, C B F$ cortex - Vmean: $\mathrm{r}=0.77 ; P<0.001$; CBF brainstem - Vsyst: $\mathrm{r}=0.82, \mathrm{CBF}$ brainstem - Vmean: $\mathrm{r}=0.69$ $P<0.05$ ). The Figure shows changes in brainstem CBF correlated with Vmean as a function of arterial hypertension.

\section{Discussion}

Several investigators have evaluated the cerebral autoregulatory range during anaesthesia. These reports indicate an upper limit of cerebral autoregulation of 150-180 mmHg. ${ }^{8-10}$ The present results show that angiotensin-induced arterial hypertension to blood pressure levels above $200 \mathrm{mmHg}$ increases cortical, brainstem and cerebellar blood flow by $64-87 \%$. This is consistent with a pressure passive cerebral perfusion due to an exhausted autoregulatory response. ${ }^{2,11,12}$ The increase in 
TABLE II Regional cerebral blood flow and TCD-data before and after induction of hypertension

\begin{tabular}{lclllllll}
\hline & $\begin{array}{l}C B F \\
\text { cortex }\end{array}$ & $\begin{array}{l}C B F \\
\text { brainstem }\end{array}$ & $\begin{array}{l}\text { CBF } \\
\text { cerebellum }\end{array}$ & ICP & CVR & Vsyst & Vmean & $P I$ \\
\hline Baseline 1 & $100 \pm 15$ & $113 \pm 44$ & $85 \pm 11$ & $1 \pm 0.5$ & $1.34 \pm 0.2$ & $22 \pm 2$ & $16 \pm 2$ & $0.7 \pm 0.1$ \\
Baseline 2 & $93 \pm 14$ & $117 \pm 45$ & $75 \pm 15$ & $1 \pm 0.5$ & $1.46 \pm 0.4$ & $21 \pm 2$ & $16 \pm 2$ & $0.7 \pm 0.1$ \\
Hypertension & $178 \pm 17^{*}$ & $212 \pm 80^{*}$ & $140 \pm 23^{*}$ & $2 \pm 1$ & $1.32 \pm 0.6$ & $28 \pm 3 \dagger$ & $21 \pm 2 \dagger$ & $1.0 \pm 0.1 \dagger$ \\
\hline
\end{tabular}

CBF in $\mathrm{ml} \cdot 100 \mathrm{~g}^{-1} \cdot \mathrm{min}^{-1}$; ICP: intracranial pressure; ICP in $\mathrm{mmHg}$; CVR: cerebral vascular resistance; CVR in $\mathrm{mmHg} \cdot \mathrm{ml}^{-1} \cdot 100 \mathrm{~g}^{-1} \cdot \mathrm{min}^{-1}$; Vsyst: systolic flow velocity; Vmean: mean flow velocity; Vsyst and Vmean in $\mathrm{cm} \cdot \mathrm{sec}^{-1}$; PI: pulsatility index; mean \pm SEM.

$* P<0.001$ compared with baseline 1 .

$\dagger P<0.05$ compared with baseline 1 .

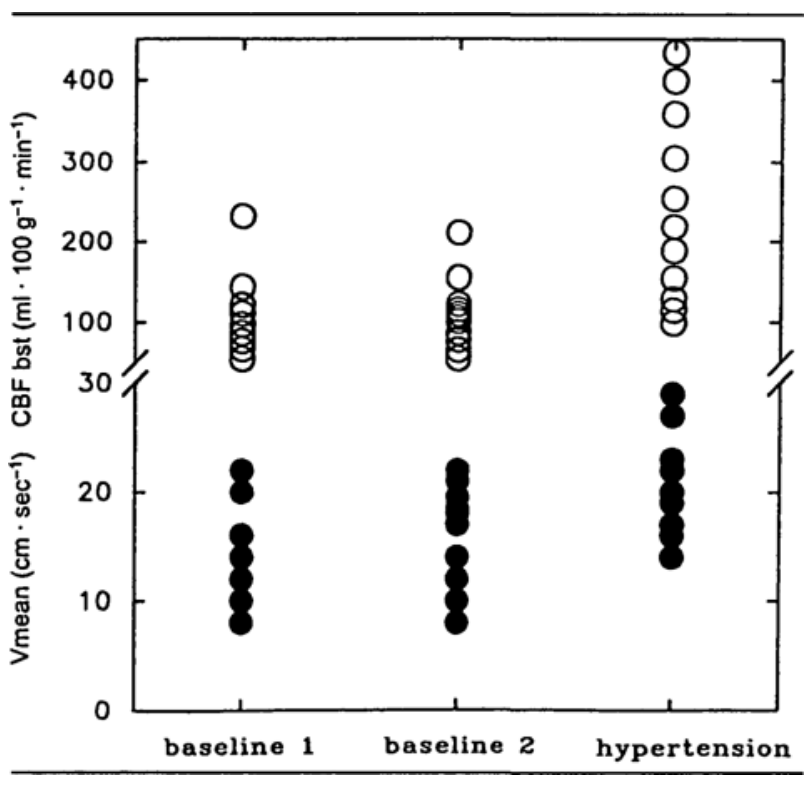

FIGURE Changes in brainstem CBF (CBF bst) and mean blood flow velocity (Vmean) in the basilar artery before and after induction of arterial hypertension.

CBF was indicated by increases in TCD blood flow velocity by $27-31 \%$. These data suggest that TCD is a monitor of increases in CBF beyond the upper limit of cerebral autoregulation.

Previous correlation studies using the microsphere technique and TCD have shown concurrent changes in $\mathrm{CBF}$ and cerebral blood flow velocity during anaesthesia. ${ }^{3,4}$ In this study, changes in CBF were correlated with changes in TCD velocity. However, the amount of increase in CBF was higher than the increase in velocity. Several factors may contribute to a non-linear relation between flow and velocity during hypertension. Doppler measurements are sensitive to changes in the diameter of the insonated vessel segment by the 4th dimension of the radius according to the law of Poisseuille. Using the cranial window technique, MacKenzie et al. ${ }^{11}$ and Kontos et al. ${ }^{12}$ observed forced dilatation of large and small cerebral arteries during hypertension. It is likely that the sudden increase in transmural pressure produced by angiotensin injection dilated the insonated segment of the BA. Thus, the increase in $\mathrm{CBF}$ during hypertension was a function of arterial dilatation and increases in blood flow velocity. The ICP was at atmospheric pressure during the experiments. This is probably due to the $35 \mathrm{~mm}$ cranial window which may allow the cranial contents to freely expand. It is possible that the diameter of the BA increases by a greater magnitude during atmospheric ICP than if the cranial contents are enclosed thus affecting the velocity measurements. Controversy exists concerning the effects of angiotensin on the cerebral vasculature. Several experiments by Edvinsson et al. ${ }^{13}$ Wei et al. ${ }^{14}$ and Joyner et al. ${ }^{15}$ show that angiotensin may act as a cerebral vasoconstrictor in cats and hamsters. This is consistent with experiments by Patel et al. ${ }^{16}$ suggesting that angiotensin has intrinsic cerebral vasoconstrictive effects in rabbits under $1 \mathrm{MAC}$ isoflurane anesthesia. In contrast, Haberl et al. ${ }^{17,18}$ have shown in rats and rabbits that angiotensin degradation products produce endothelium-dependent dilatation of brain arterioles. The results from these studies suggest that the effects of angiotensin on the cerebral vessels may be species-specific. It is unclear whether either of these mechanisms affect the diameter of the BA. Endothelium-dependent dilatation of brain vessels may have contributed to both pressure passive increases in $\mathrm{CBF}$ and the underestimation of these increases by TCD velocity measurements. However, it is more likely that changes in arterial diameter were related to hypertension rather than direct effects of angiotensin.

During the present study, the baseline values of blood flow velocity in the BA were lower than velocities measured in the middle cerebral artery (MCA) during previous experiments. ${ }^{3,4}$ There are two possible explanations for this: Doppler ultrasound measurements are dependent on changes in the angle between the ultrasonic beam and the insonated vessel. It is possible that the angle between the vessel and the beam was $>30^{\circ}$ during the present experiments and was different compared to previous studies. This would lead to measurement of errors of $>15 \%$ with respect to true velocity. ${ }^{19}$ It is also possible that physiological variations in vascular diameter produced 
differences in TCD measurements between supra- and infratentorial vessels. This would be consistent with the large variability in TCD measurements observed in humans. ${ }^{5,19}$ During the present experiments, TCD blood flow velocity was measured in the BA following a craniotomy at the vertex area between both parietal bones. In dogs, a craniotomy is necessary since the ultrasonic beam cannot penetrate the thick cranial bones. In patients, TCD blood flow velocity can be measured noninvasively in supratentorial (MCA) and infratentorial vessels (BA). It is important to keep the insonation depth and insonation angle constant during the investigations in humans and animals. This allows comparison of TCD measurements over time. However, absolute CBF values cannot be inferred from TCD measurements.

The pulsatility index (PI) has been reported to be an approximation of cerebral vascular resistance. ${ }^{5,20,21}$ However, the poor correlation between PI and CVR during the present study suggests that additional factors may produce changes in PI. Dewey et al. ${ }^{22}$ have shown that CBF is determined by four major factors: intracranial pressure (ICP), critical closing pressure (CCP) which represents vasomotor tone, MAP and the dynamic pressure flow relationship (DPFR), which represents the cerebral vascular resistance. The data from the experiments by Dewey et al ${ }^{22}$ indicate that CCP but not DPFR is raised with increases in MAP. Their data suggest that the autoregulatory response is due to changes in vasomotor tone rather than changes in vascular diameter. During the present study, CVR did not change but PI was increased during arterial hypertension. According to Dewey et al. ${ }^{22}$ it is possible that the analysis of the pulsatile flow velocity pattern (PI) by TCD may represent changes of vasomotor tone rather than cerebral vascular resistance during increases in MAP.

Coloured microspheres were used to measure $\mathrm{CBF}$ in these present experiments. Until now, most studies have used radioactive microspheres to measure CBF. In a study comparing nonradioactive, coloured microspheres with radioactive microspheres for measurement of regional myocardial blood flow, Hale et al. ${ }^{7}$ found excellent correlations for the two techniques. However, at high-flow values, coloured microspheres yielded blood flow values $39 \%$ higher than the values computed by radioactive microspheres. In an incomplete ischaemia model in goats, Kochs et al. ${ }^{23}$ have shown a close correlation between rCBF measured with coloured microspheres and CBF using an electromagnetic flow probe placed on the internal maxillary artery. The reproducibility of measurements using coloured microspheres is also supported by the fact that there were no differences in CBF for the two baseline measurements in the present study. These data suggest that the nonradioactive, coloured micro- sphere technique is a valid measure of $\mathrm{CBF}$ in a dog model. However, true organ blood flow may be overestimated during high-flow states.

Increases in mean arterial blood pressure may occur at any stage during anaesthesia and critical care. In patients with reduced intracranial compliance and impaired $\mathrm{CBF}$ autoregulation, pressure-dependent $\mathrm{CBF}$ may produce deleterious increases in intracranial pressure. The present results show that TCD is a monitor of relative changes in $\mathrm{CBF}$ during arterial hypertension. This suggests that continuous and noninvasive TCD monitoring may prevent the brain from hyperperfusion particularly in situations where clinical evaluation of adequate cerebral perfusion is impossible. However, arterial hypertension was induced using a large, $1.25 \mathrm{mg}$, angiotensin dose which produced a dramatic increase in cerebral perfusion pressure. It is unclear whether the TCD technique is sensitive enough to demonstrate changes in CBF over a smaller pressure range. Further studies will have to evaluate the correlation between CBF and TCD blood flow velocity over mild to moderate alterations in arterial blood pressure.

In conclusion, our results show that angiotensininduced acute arterial hypertension beyond the upper limit of cerebral autoregulation increases CBF and blood flow velocity in the $B A$. The correlation between relative changes in cerebral blood flow velocity and CBF suggests that TCD is a useful monitor to indicate changes in brain perfusion beyond the upper limit of autoregulation. However, the amount of increase in CBF was underestimated by TCD. This is most likely due to the sudden increase in transmural pressure with concurrent dilatation of the insonated vessel segment.

\section{Acknowledgement}

The authors wish to thank Marianne Pedersen, Andrea Oldag, Doris Droese and Monika Schmersahl for their technical assistance.

\section{References}

1 Rapela CE, Green $H D$. Autoregulation of canine cerebral blood flow. Circ Res 1964; 14 (Suppl 1): 205-11.

2 Busija DW, Heistad DD. Factors involved in the physiological regulation of the cerebral circulation. Rev Physiol Biochem Pharmacol 1984; 101: 161-211.

3 Werner C, Hoffman WE, Kochs E, Albrecht RD, Schulte am Esch $J$. The effects of propofol on cerebral blood flow in correlation to cerebral blood flow velocity in dogs. Journal of Neurosurgical Anesthesia 1992; 4: 41-6.

4 Werner C, Hoffman WE, Baughman VL, Albrecht RF, Schulte am Esch $J$. Effects of sufentanil on cerebral blood flow, cerebral blood flow velocity, and metabolism in dogs. Anesth Analg 1991; 72: 177-81. 
5 Pilato MA, Bissonnette B, Lerman J. Transcranial Doppler: response of cerebral blood-flow velocity to carbon dioxide in anaesthetized children. Can J Anaesth 1991; 38: 37-42.

6 Van der Linden JA, von Ahn H, Ekroth $R$, Tydén $H$. Middle cerebral artery blood flow velocity during coronary surgery; influences of clinical variables. $\mathrm{J}$ Clin Anesth 1990; 2: 7-15.

7 Hale SL, Alker KJ, Kloner RA. Evaluation of nonradioactive, colored microspheres for measurement of regional myocardial blood flow in dogs. Circulation 1988; 78 : 428-34.

8 Hoffman WE, Werner C, Kochs E, Segil L, Edelman G, Albrecht RF. Cerebral and spinal cord blood flow in awake and fentanyl $/ \mathrm{N}_{2} \mathrm{O}$ anesthetized rats: evidence for preservation of blood flow autoregulation during anesthesia. Journal of Neurosurgical Anesthesia 1992; 4: 31-5.

9 Sokrab TE, Johansson BB. Regional cerebral blood flow in acute hypertension induced by adrenaline, noradrenaline and phenylephrine in the conscious rat. Acta Physiol Scand 1989; 137: 101-6.

10 Hernandez MJ, Brennan RW, Bowman GS Cerebral blood flow autoregulation in the rat. Stroke 1978; 9: 150-4.

11 MacKenzie ET, Strandgaard S, Graham DI, Jones JV, Harper $A M$, Farrar $J K$. Effects of acutely induced hypertension in cats on pial arteriolar caliber, local cerebral blood flow, and the blood-brain barrier. Circ Res 1976; 39: 33-41.

12 Kontos HA, Wei EP, Navari RM, Levasseur JE, Rosenblum WI, Patterson $J L J$ r. Responses of cerebral arteries and arterioles to acute hypotension and hypertension. Am J Physiol 1978; 234: H371-83.

13 Edvinsson L, Hardebo J-E, Owman C. Effects of angiotensin II on cerebral blood vessels. Acta Physiol Scand 1979; 105: 381-3.

14 Wei EP, Kontos HA, Patterson JL Jr. Vasoconstrictor effect of angiotensin on pial arteries. Stroke 1978; 9: 487-9.

15 Joyner $W L$, Young $R$, Blank D, Ecclestone-Joyner CA, Gilmore JP. In vivo microscopy of the cerebral microcirculation using neonatal allografts in hamsters. Circ Res 1988; 63: 758-66.

16 Patel PM, Mutch WAC. The cerebral pressure-flow relationship during 1.0 MAC isoflurane anesthesia in the rabbit: the effect of different vasopressors. Anesthesiology 1990; 72: 118-24.

17 Haberl RL, Decker PJ, Einhäupl KM. Angiotensin degradation products mediate endothelium-dependent dilation of rabbit brain arterioles. Circ Res 1991; 68: 1621-7.

18 Haberl RL, Anneser F, Villringer A, Einhäupl KM. Angiotensin II induces endothelium-dependent vasodilatation of rat cerebral arterioles. Am J Physiol 1990; 258: H1840-6.
19 Aaslid R. Transcranial Doppler Sonography. Wien, New York: Springer Verlag, 1986.

20 Giulioni $M$, Ursino $M$, Alvisi $C$. Correlations among intracranial pulsatility, intracranial hemodynamics, and transcranial Doppler wave form: literature review and hypothesis for future studies. Neurosurgery 1988; 22: 807-12.

21 Klingelhöfer J, Conrad B, Benecke R, Sander D, Markakis $E$. Evaluation of intracranial pressure from transcranial Doppler studies in cerebral disease. J Neurol 1988; 235: 159-62.

22 Dewey RC, Pieper HP, Hunt WE. Experimental cerebral hemodynamics - vasomotor tone, critical closing pressure, and vascular bed resistance. $J$ Neurosurg 1974; 41 : 597-606.

23 Kochs E, Schulte am Esch J. Somatosensory evoked responses during and after graded brain ischemia in goats. Eur J Anaesthesiol 1991; 8: 257-65. 